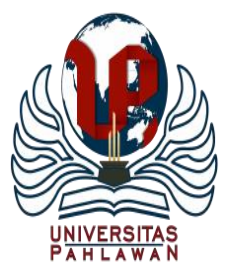

Edukatif : Jurnal Ilmu Pendidikan Volume 3 Nomor 4 Tahun 2021 Halm 1283 - 1297

EDUKATIF: JURNAL ILMU PENDIDIKAN

Research \& Learning in Education

https:/ledukatif.org/index.php/edukatif/index

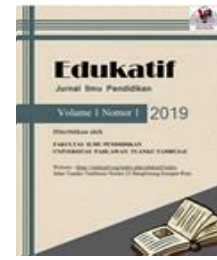

\title{
The Existence Condition Of Environment And Disaster Literacy At Elementary School Student Mother In Bogor West Java
}

\author{
Bahagia $^{1 凶}$, Fachruddin Majeri Mangunjaya ${ }^{2}$, Rimun Wibowo $^{3}$, Zulkifli Rangkuti ${ }^{4}$ \\ Universitas Ibn Khaldun Bogor, Indonesia ${ }^{1}$ \\ Universitas Nasional, Indonesia ${ }^{2}$ \\ STIMA IMMI Jakarta, Indonesia ${ }^{3,4}$ \\ E-mail: $\underline{\text { bahagiagia59@yahoo.co.id }}{ }^{1}, \underline{\text { mangunjaya@ }}$ civitas.unas.ac.id $^{2}, \underline{\text { rimunwibowo@gmail.com }}^{3}$, \\ zrangkuti@gmail.com ${ }^{4}$
}

\begin{abstract}
Abstrak
Penelitian ini bertujuan untuk mengetahui penyuluhan bencana untuk meningkatkan literasi lingkungan dan bencana, peran dinas bencana dalam meningkatkan pengetahuan tentang bencana. Tujuan lainnya adalah untuk mengetahui perilaku ibu siswa dalam menghadapi bencana melalui literasi bencana. Metode yang digunakan adalah kualitatif dengan analisis deskriptif. Metode ini diterapkan karena penelitian terkait dengan survei. Pengumpulan data dilakukan melalui kuesioner, wawancara, observasi dan dokumentasi. Pemilihan informan menggunakan teknik purposive sampling. Hasilnya diteliti dengan cermat melalui analisis persentase. Hasil penelitian menunjukkan bahwa ibu siswa dilibatkan dalam penyuluhan bencana sehingga dapat meningkatkan sikap, pengetahuan, dan perilaku. Temuan lainnya adalah para ibu siswa mengetahui tentang peran dan fungsi lembaga kebencanaan untuk meningkatkan literasi mereka biasanya informasi tentang kebencanaan. Terakhir, perilaku ibu siswa yang belum dilaksanakan dengan baik seperti tindakan pengurangan resiko bencana dan perbaikan lingkungan dari rumahnya termasuk belum memanen air hujan dengan baik, kurang berperilaku membudidayakan tanaman dan pohon buah-buahan. Sekaligus mereka belum menciptakan daerah resapan sebagai tempat menyimpan air hujan. Penelitian berkontribusi sebagai dasar pertimbangan pembuatan kebijakan literasi bencana bagi pemerintah dan pihak swasta yang ikut terlibat dalam literasi bencana.
\end{abstract}

Kata kunci: Bencana, banjir, Iklim, Literasi, dan ibu siswa

\begin{abstract}
This study aims to determine disaster education to increase environmental and disaster literacy, the role of the Disaster Agency in increasing knowledge about disasters. Another objective is to determine the behavior of student mothers in dealing with disasters through disaster literacy. The method used is qualitative with descriptive analysis. This method is applied because the research is related to the survey. Data collection was carried out through questionnaires, interviews, observation, and documentation. Selection of informants using a purposive sampling technique. The results are scrutinized through an analysis of percentages. The results showed that the students' mothers were involved in disaster education to improve attitudes, knowledge, and behavior. Another finding is that the students know about the role and function of disaster institutions to increase their literacy, general information about disasters. Lastly, the behavior of the student's mother that has not been implemented properly, such as disaster risk reduction and environmental improvement of the house, includes not harvesting rainwater properly, less behavior in cultivating plants and fruit trees. At the same time, they have not created catchment areas for storing rainwater. Research has a contribution to the government to create disaster literacy policy as well as the private sector which participates in disaster literacy.
\end{abstract}

Keywords: Disaster, Environment, Flooding, Literacy, mother of student

Copyright (c) 2021 Bahagia, Fachruddin Majeri Mangunjaya, Rimun Wibowo, Zulkifli Rangkuti

Corresponding author:

Email : bahagiagia59@yahoo.co.id

DOI : https://doi.org/10.31004/edukatif.v3i4.508

ISSN 2656-8063 (Media Cetak)

ISSN 2656-8071 (Media Online)

Edukatif : Jurnal Ilmu Pendidikan Vol 3 No 4 Tahun 2021 p-ISSN 2656-8063 e-ISSN 2656-8071 
1284 The Existence Condition Of Environment And Disaster Literacy At Elementary School Student Mother In Bogor West Java - Bahagia, Fachruddin Majeri Mangunjaya, Rimun Wibowo, Zulkifli Rangkuti

DOI: https://doi.org/10.31004/edukatif.v3i4.508

\section{INTRODUCTION}

Indonesia still confronts environmental damaged and ecology disasters including flooding, land sliding, drying as well as climate change. Indonesia is vulnerable to a natural disaster because the location of Indonesia is placed on three tectonic plates as plate pacific, Eurasia, and Indo-Australia. As a consequence, it makes this country very susceptible to numerous disasters such as Tsunami, earthquakes, volcanic eruptions, and other kinds of disasters. Besides, Indonesia is one country that is located in khatulistiwa line so the region must be a tropic climate. As result, when a heavy rain comes, it triggers flooding and drying, and wind disaster. Meanwhile, as the drying season occurs, it refers to drying, land, and forest fire (Yanuarto et al., 2019). Meanwhile, the second-highest number of flooding calamities is West Java about 105 times and the thirdly rank of wind tornado disaster about 252 times (Andianti, Mardiyah \& Purba, 2020). Eco-catastrophe has a connection to literacy application in school as education for disaster.

Generally, there is numerous substance in eco-literacy including the knowledge about environmental issues, ecology, social and issue of politics, cognitive skills, and the cause of human behavior for responsible in the environment (Leksono et al., 2020). Rusmawan, (2017) reveals that eco-literacy depicts the pivotal aspect of the environment. Ecoliteracy can be attained when individuals aware of how the essential environment, How pivotal to secure and nurture the earth, ecosystem, and nature as the habitat of life. Ecoliteracy can transform society's understanding and introduce to societies the important aspect of global ecology consciousness (Utaya \& Bachri, 2019). Ecology literacy can be achieved when there is integration between action and learning. For example, the students can jump their knowledge to the environment when biology material at class must be implemented in the field directly like for creating bio-pory (Prastiwi et al., 2020). As result, the emerging of environmental literacy can provide people who comprehend and surmount environmental obstacles so that environmental agents who have a caring attitude towards the environment can be prepared (Wilujeng et al., 2019). Meilinda et al., (2017) environment literacy covers some of the aspects that encompass knowledge, attitude, and environmental concern. Meanwhile, to describe citizen literacy to the environment must be connected to some aspects such as environmental sensitivity, knowledge, skills, attitude, and values, personal investment, responsibility, and active involvement (Veisi et al., 2019). It must be bolstered by that attitude, knowledge, and behaviors are considered as a factor in eco-literacy (Gheith, 2019). In previous research show that ecological knowledge, cognitive skills, attitude, and behavior have correlated to environmental literacy (Indri Safitri et al., 2020).

From some theory can be described that environment literacy has a strong linkage to the consciousness, attitude, knowledge, and action or behavior of people for protecting nature because human need nature as habitat and feed the human, as well as human, must be responsible for nature damaged like deforestation, pollution, and another devastating environment. Besides environment literacy, humans need disaster ecology literacy to understand the cause and how to behave to disaster when it combats human life. Environmental Statistics (2016) remark that a natural disaster is a natural event that can wreak havoc and threaten human habitats and life. Natural disasters can also disturb the balance of the environment. Then the definition of disaster also relates to products or man-made and is known as technological disasters. Technological disasters or man-made hazards are events that are caused by humans and occur in/near human settlements. Technology disasters arise as a result of negligence or errors in the application of technology.

Technological disasters include, among others, industrial accidents and transportation accidents. Destructive behavior and activities carried out by humans can play a role in increasing the frequency and severity of disasters that occur, for example, deforestation can cause flooding, landslides, and drought. In addition, the definition of disaster according to Law No. 24 of 2007 is non-natural disasters including forest/land fires caused by humans, transportation accidents, construction/technology failures, industrial impacts, nuclear explosions, environmental pollution, and space activities. Brown et al.,(2014) said that 
1285 The Existence Condition Of Environment And Disaster Literacy At Elementary School Student Mother In Bogor West Java - Bahagia, Fachruddin Majeri Mangunjaya, Rimun Wibowo, Zulkifli Rangkuti DOI: https://doi.org/10.31004/edukatif.v3i4.508

disaster literacy is the individual's ability to read, understand, and use the information to make decisions and follow instructions in the context of reducing, preparing, responding so that they recover from disasters, also, disaster literacy to aware of society's disasters. Society who doesn't know about disaster information will be perplexed what the sots of disaster, how to deal with it, and how to confront that disaster (Murdiyanto \& Gutomo, 2018). Disaster literacy can be categorized as an endeavor to aware of the societies about ecology disaster. It makes the societies conscious that their location is prone to ecocatastrophe (Afrian \& Islami, 2019). Kusumastuti \& Kurniawan,(2020) remark that literacy activities are carried out in the form of showing disaster preparedness videos made by BNPB and quiz feedback. In addition, the disaster preparedness information props were also made in the form of standing banners that were easy and interesting to read. To boost this theory must be encouraged by some previous discovering. Previous research findings can be seen in Table 1 below. To find variables and indicators in this study, several previous studies were presented in tabular form.

Tabel 1

Finding last researh about disaster literacy

\begin{tabular}{|c|c|c|}
\hline Name & Topic & Discovering \\
\hline (Priyowidodo \& Luik, 2013) & 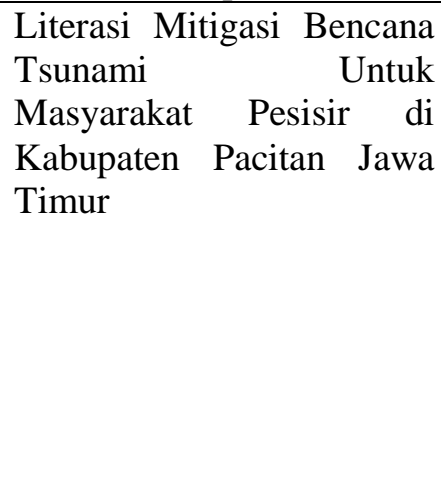 & $\begin{array}{l}\text { About } 68 \% \text { of respondents indicated that the } \\
\text { respondents had no knowledge of the } \\
\text { existence of the BPBD institution. The } \\
\text { community does not have sufficient } \\
\text { awareness of the tsunami hazard. Even though } \\
\text { their level of knowledge is sufficient for all } \\
\text { information about the tsunami, they feel that } \\
\text { the role of the government must be optimized, } \\
\text { so that the community does not have } \\
\text { excessive anxiety in the event of an } \\
\text { earthquake followed by a tsunami. }\end{array}$ \\
\hline (Marlyono, 2017) & $\begin{array}{lr}\text { Pengaruh } & \text { Literasi } \\
\text { Informasi } & \text { Bencana } \\
\text { Terhadap } & \text { Kesiapsiagaan } \\
\text { Masyarakat } & \text { Dalam } \\
\text { Menghadapi } & \text { Bencana di } \\
\text { Provinsi Jawa Barat }\end{array}$ & $\begin{array}{l}\text { The impact of disaster information literacy on } \\
\text { community preparedness is up to } 45 \% \text {. } \\
\text { Information literacy consists of } 4 \text { indicators, } \\
\text { namely (1) identifying and finding } \\
\text { information }(36 \%) \text {; (2) evaluating information } \\
(25 \%) \text {; (3) organizing and integrating } \\
\text { information (26\%); (4) utilize and } \\
\text { communicate information effectively legally } \\
\text { and ethically (26\%). }\end{array}$ \\
\hline (Indriantoro, 2014) & $\begin{array}{lr}\text { Pengetahuan } & \text { Masyarakat } \\
\text { Terhadap } & \text { Mitigasi } \\
\text { Bencana } & \\
\text { Kekeringan di } & \text { Kecamatan } \\
\text { Tawangsari } & \\
\text { Kabupaten Sukoharjo }\end{array}$ & $\begin{array}{l}\text { The rate of public knowledge about drought } \\
\text { disasters } \\
78 \% \text { was in the good category, while at the } \\
\text { community mitigation level } 36.7 \% \text { was in the } \\
\text { moderate category. }\end{array}$ \\
\hline (Puspitasari, 2014) & $\begin{array}{l}\text { Tingkat Pengetahuan } \\
\text { Siswa Kelas VII dalam } \\
\text { Mitigasi Bencana Gempa } \\
\text { Bumi di SMP Negeri 1 } \\
\text { Prambanan Kabupaten } \\
\text { Klaten }\end{array}$ & $\begin{array}{l}\text { Knowledge was categorized as quite good } \\
\text { with a percentage of } 51.2 \% \text {, followed by a } \\
\text { good category with a percentage of } 45.7 \% \text { and } \\
\text { a poor category with a percentage of } 3.1 \% \text {. }\end{array}$ \\
\hline
\end{tabular}

Based on previous research discovering and some theory supporting the environment and disaster literacy, this research intends to continue in another aspect that has a stringent connection to disaster and environment literacy. The research focuses on the condition of the existence of the environment and disaster 
1286 The Existence Condition Of Environment And Disaster Literacy At Elementary School Student Mother In Bogor West Java - Bahagia, Fachruddin Majeri Mangunjaya, Rimun Wibowo, Zulkifli Rangkuti DOI: https://doi.org/10.31004/edukatif.v3i4.508

literacy in mothers of students at elementary school which the school near to Ciliwung river. The objective of this research is to discover about the extension typically for disaster which is conducted by disaster agency to increase environmental and disaster literacy as well as the knowledge of women parent about the role of Disaster agency to scale up the knowledge about the disaster because they obtain information about the disaster in women parent at School. The other purpose is to find out about the behavior of mothers of the student for confronting disasters both in the environment and disaster literacy.

\section{METHOD}

This research on the existing condition of environment and disaster literacy at elementary school parents in Bogor West Java. The research was conducted in some elementary school in Bogor including SD Sempur Kidul, Sempur Kaler, Katulampa 1, Katulampa 2, and Katulampa 3. The location is selected because the school is close to the Ciliwung River. The research method use is descriptive with a quantitative approach. Priyono, (2016) remarks that descriptive research can be defined as the research was conducted to provide an overview in more detail about a symptom or phenomenon. The result at the end of the research is usually typology or patterns regarding the phenomenon that is being discussed.

Descriptive research is conducted by searching for information associated with existing symptoms, described clearly the goals to be achieved, plan how to do his approach, and collect a variety of kinds of data as materials for making the report. Meanwhile, the quantitative approach is used because the research exerts numeric which is utilized from gathering data, interpretative data, and the result of research (Arikunto, 2013). To collect the sample as respondent exert purposive technique. Purposive sampling can be mentioned as a non-random sampling technique where the researcher determines with some pondering suited with the goal of the research. As result, It can answer suited with the research issues which intent to obtain (Hidayat, 2017).

The respondents in this research have been determined by the head of school through the gathering of the mother of a student at Elementary school where the school close to the Ciliwung River. The reason is the mothers need to know about the disaster because they settle in the vicinity of the Ciliwung River which must be vulnerable are for the living. Even it link to the way of mother student at Elementary school to secure their children when a disaster occurs rapidly because they watch their children at school and pick up their kids after completing time school learning. The sample has been determined directly around 100 mothers of an elementary school student. The researcher perceives that the sample can be categorized as the best sample because the sample can reply to the question considered with the environment and disaster literacy.

Meanwhile, for collecting data, the researcher exerts three sorts of methods including Quisioner and interview, using observation and interview as well as documentation. Researchers use questioner for collecting data related to some questions such as whether there was an extension comes from a disaster agency to add the mother of an elementary school in the environment and disaster literacy. The other question focuses on the action or behavior immediately in their house to release environment and disaster literacy for reducing the risk of a natural disaster. It must be supported by the question about the knowledge in environment and nature disaster to reduce disaster because they have liberated like their knowledge in disaster agency role in reducing disaster.

The question has been adjusted like a list question where the respondent can select which is suited to their perspective while observation is used to observe directly the location and the condition of the environment where the sample dwells. The data which have been collected will be tested through percentage. A simple analysis of percentages by determining the range of the lowest and highest scores by diverting the number of respondents (n) with the highest weight minus the lowest weight, then divided by the number of categories of item answers.

Formula: $\mathrm{RS}=\mathrm{n} \underline{\text { (largest value }- \text { smallest value) }}$ 
1287 The Existence Condition Of Environment And Disaster Literacy At Elementary School Student Mother In Bogor West Java - Bahagia, Fachruddin Majeri Mangunjaya, Rimun Wibowo, Zulkifli Rangkuti DOI: https://doi.org/10.31004/edukatif.v3i4.508

Where:

RS = Scale Range

$\mathrm{n} \quad \quad=$ Number of Respondents

$\mathrm{m} \quad=$ Number of Categories

The findings that have been obtained will be tested with this formula so that the percentage trend of each variable under study is known. The results are presented in tabular form as well as in bar graph form so that the percentage of each variable studied is known. After that, it is discussed by comparing and searching support for other research findings that come from various scientific articles or previous research results.

\section{RESULT AND DISCUSSION}

Extension of disaster is defined as an informal school that aims to change attitudes, behavior, and public awareness of disasters. When disaster education materials are carried out, they can directly change attitudes, behavior, knowledge, and public awareness. Attitude is categorized as the readiness of an individual to action and behavior the real action of individuals. The success of environmental extension activities can be seen from changes in community behavior. This research proves that disaster education has not been carried out optimally, likewise with environmental education, whereas disaster and environmental education for disasterprone communities such as those on the banks of the Ciliwung River are very important. The picture of the involvement of mothers of primary school children can be seen in Figure 1 below.

\section{The percentage of mother of student involvement in extension activity}

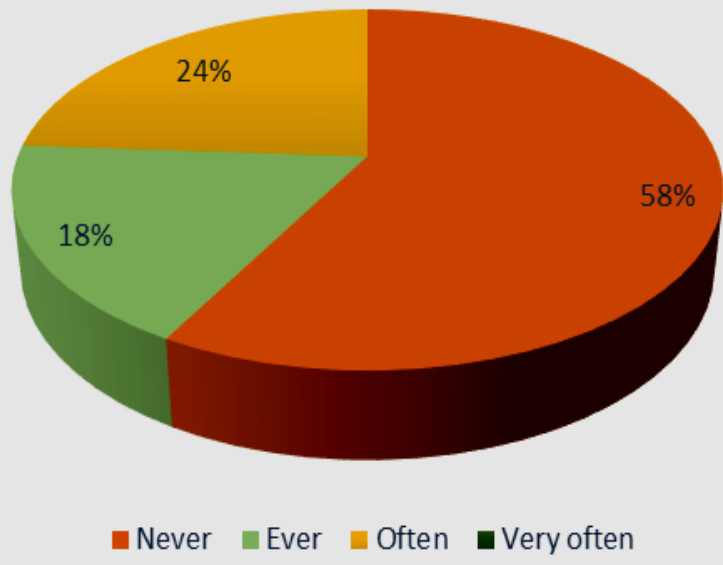

\section{Figure 1. Percentage of Community Participation in Disaster and Environmental Extension Activities}

Based on this pie chart, it gives information that the mother of a student at elementary school has a lack of involvement in disaster extension. The pie chart shows that the widest number of mother student never includes in extension activity around 58 percent of 100 mothers of student and the percentage of mother student often leave in extension program is about 18 percent, as well as the slowest number of the respondent joint in extension, is about 24 percent. It shows that when the mother blend to follow the extension can scale up the capacity of literate in disaster ecology including the clue of disasters like flooding, land sliding, and the alteration of climate which can be treacherous for human. In addition, it can increase the knowledge in environment function to save nature function to support human life and reduce the risk of disaster.

In this finding explain that the mother of student have a shortage of knowledge in disaster because the biggest number of mother student don't week in an extension activity. As a result, it doesn't react in their 
behavior to deal with ecology disaster as well as the temper in an environment like releasing a behavior in cultivating the trees and another plant to conserve the environment where they live. The impact is the mother can be vulnerable to disaster because they lack information in a disaster. Some finding reveals that it is significantly different between the people who have joined extension activity rather than the people who have not involved in extension. When the people join, it can jump the level of their knowledge instead of before they mix in extension activity (Yusuf \& Kurnia Mangile, 2019).

In another discovering inform that the extension activity can impact the readiness of a disaster (Sasikome et al., 2015). It must be bolstered by education in behavior to jump the preparedness of people for confronting disasters like flooding (Yaslina \& Taufik, 2018). Even there is a strong correlation between knowledge, attitude, and boosting from the family to reach preparedness in disaster (Supriandi, 2020). The knowledge also has a connection to increase the rate of charity of people and attitude toward readiness in facing disaster (Kurniawati \& Suwito, 2019). Furthermore, the purpose of environment extension is to make people understand about an endeavor to nurture the environment despite only cultivating the plant at home as well as supporting the behavior in protecting plants and animals (Khairuddin et al., 2019). The differences of temper in some individuals because individuals face differences in the environment and situation and culture can be mentioned as other factors to influence the people behavior (Syamaun, 2019).

Based on the results of this study, it can prove that disaster and environmental education is still not optimal. Meanwhile, the extension is classified as one of the ways to improve attitudes, awareness, and behavior towards disaster-resilient communities. The more frequent extension activities are carried out, the more likely it is that the community will be literate on disaster and environmental literacy because students in schools that are prone to disasters will gain knowledge about ecosystem functions, climate change, causes of floods and landslides, and how to control disasters through environmental extension activities. The impact is that community resilience to disasters has not been achieved properly.

The community needs to understand and know the duties and roles of both disaster management agencies from private disaster management agencies such as NGOs and the government. Disaster agencies have to educate people so that they understand the signs of an impending disaster in their area. The public can know about these duties and roles if this institution is close to people in areas prone to natural disasters. At the same time, they have to actively disseminate information to the community about the duties and roles of all communities in areas prone to natural disasters. The weaker role of the disaster agency in providing disaster information to the community has an impact on weakening the community's ability to receive disaster information.

People are not aware of disasters and even fail in the long run to mitigate natural disasters, from floods and landslides and other disasters that may occur. Communities cannot be left alone to carry out mitigation without support from the government under regional disaster institutions. It is more ironic if the community does not know and does not understand that disaster agencies are dealing with natural disasters. The number of mothers of students who literate in disaster agency roles can be viewed in figure 2 below. 


\section{The Knowledge of mother student in disaster agency}

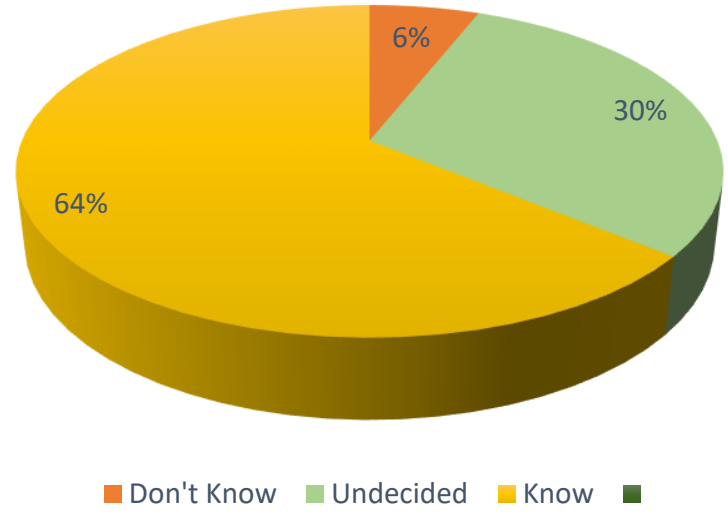

Figure 2. The knowledge of mother student in disaster agency.

These findings prove that public literacy towards disaster institutions is very good. The number of people who already know about the disaster agency as an institution that functions to save lives from disasters reaches 64 percent. Meanwhile, there was about 30 percent of the people were still doubtful about the function of the institution, and the people who did not know the role and function of the agency or institution were about 6 percent of the 100 respondents interviewed. This fact is proof that the stakeholders involved in disaster management are very close to the social environment of the community so that any time when a disaster occurs, they can be saved. Mapping disaster-prone areas must involve the participation of layers of society so that they know that there is a natural disaster management agency. This directly proves that community literacy, namely to obtain information related to disaster agencies, is adequate. At the same time, increasing the community's ability to obtain information on disasters, the environment, and at one time even being able to independently carry out disaster mitigation.

This will have an impact on reducing social problems ranging from poverty because a lot of property is damaged by the disaster, reducing the number of casualties and the sick due to the disaster. However, disaster management is not only assigned to disaster management agencies, both government and private. However, geography teachers can also be at the forefront as agents of disaster management, for example, the involvement of the Indonesian National Army (TBI) in disaster management. The role of the TNI in disaster management starts from the pre-disaster (pre-disaster) process, during disaster response, and post-disaster. Activities carried out in the form of TNI service to the community such as providing socialization and social communication or providing assistance directly when a disaster occurs (Widyaningrum et al., 2020). The other roles of Indonesia National troops including rendering coaching, providing outreach directly in the community forms of mutual activity mutual assistance, among others, carrying out activities, beach/river cleaning, make a Waste-Free Declaration as a form of disaster prevention floods at the same time support the government program to reduce waste Plastic as well as the National Troop Indonesia involving in cultivating mangrove trees for dealing with disaster (Nugraha et al., 2020).

Besides, other institutions like the Indonesian Red Cross (PMI) can contribute to saving human life from disasters such as providing human resources consisting of PMI employees and volunteers from the community who are trained and spread throughout Indonesia. In addition, PMI Pusat has a team for assessing health problems and a team for rapid reaction. Facilities and equipment used by PMI including health services and medicine (Puspasari, 2017), even better if there is good cooperation in overcoming disaster problems. For example, a collaboration between institutions, both the government and the private sector, make the 
1290 The Existence Condition Of Environment And Disaster Literacy At Elementary School Student Mother In Bogor West Java - Bahagia, Fachruddin Majeri Mangunjaya, Rimun Wibowo, Zulkifli Rangkuti

DOI: https://doi.org/10.31004/edukatif.v3i4.508

community resilient in facing disasters. For example, a collaboration between the government, the private sector, and NGOs is very supportive of achieving a truly resilient community in the face of natural disasters (Yumantoko, 2019).

Behavior relates to direct actions taken by the community itself without assistance from other parties, including the government. These behaviors are classified as visible actions and individual awareness of each community to reduce disaster risk. This behavior is a manifestation that the mother of students is aware of the environment and disasters. In this behavior, there are several aspects of discovery starting from the behavior of creating a water catchment area to reduce disaster risk. A water catchment area is an area in the form of a grassy green yard, a living fence, and an area that has the power to absorb rainwater. The purpose of creating a water catchment area is to reduce the occurrence of surface flooding from rainwater. With this recharge area, the surface runoff can be reduced. The results of research on the existence of water catchment areas can be seen in Table 2 below.

Table 2

Absorbtion water area

The existance of absorbtion water zone

\begin{tabular}{ccccc}
\multicolumn{5}{c}{ The existance of absorbtion water zone } \\
\hline 1 & & Grassy Land & \multicolumn{2}{c}{ Trees and another sorts of plants } \\
\hline 2 & Have & Don't have & Have & Don't have \\
\hline Jumlah & 15 & 85 & 13 & 87 \\
\hline Total & 100 & & 100 \\
\hline
\end{tabular}

Based on the table above, the existence of water catchment areas, both grassy yards, and living fences, is rare. About 15 people out of 100 respondents have a green (grass) yard. Then, about 85 out of 100 people don't have a grassy lawn. This condition is compounded by the low ownership of trees and plants on the home page. The data illustrates that there are only 13 out of 100 students who own trees and other plants and do not have trees in the yard of the house, reaching 87 people. The function of the water catchment area is to inhibit rainwater so that it does not occur too high surface flow so that rainwater can enter the ground. The lack of water catchment areas in the environment where the community is in a disaster-prone area causes the environment to be prone to flooding. More water is wasted compared to water that is infiltrated into the soil. Communities who live on the banks of the Ciliwung River are prone to flooding of catchment areas not yet a part of their behavior.

It causes an increase in the water level due to increased water entering the river. The facts in this study indicate that catchment areas such as green areas are very minimal and have not become part of individual awareness, even though green areas such as living fences and grassy yards have an important role to play in maintaining environmental quality. With the facts above, it can be ascertained that the environment is flooded. Grassy areas have an important role to play in retaining rainwater and maintaining humidity in the home environment. The grass area helps maintain the micro-climate around the home environment. The area becomes cool because sunlight absorbs sunlight instead of being reflected again. Likewise with a house equipped with a living fence. Homes are cooler and can reduce surface flooding. The behavior to maintain a living fence has not yet grown in the environment.

Concrete and iron fences and houses without fences dominate the behavior of the community. Mitigation of floods, landslides, and climate problems can only be overcome with anticipatory action, namely by building more water catchment areas. On the other hand, Purwantara,(2015) said that flooding is a hazard if humans are not wise in their attitude. A flood can be a disaster (disaster), and can even be a disaster (catastrophe) if humans do not care anymore about the environment. A reduction in water catchment areas means an increase in surface water discharge (Dewi \& Rudiarto, 2014). Resubun et al.,(2015) stated that the loss of water catchment areas is related to the conversion from water catchment areas to residential areas and trade in goods and services. Changes in land use from areas that were previously rainwater infiltrated to areas 
1291 The Existence Condition Of Environment And Disaster Literacy At Elementary School Student Mother In Bogor West Java - Bahagia, Fachruddin Majeri Mangunjaya, Rimun Wibowo, Zulkifli Rangkuti DOI: https://doi.org/10.31004/edukatif.v3i4.508

that are watertight in urban areas have an impact on reducing rainwater catchment areas and causing surface water runoff (Harisuseno et al., 2013).

This condition is exacerbated by land that used to be water catchment areas, such as forested areas, which were then converted into non-forested land. As a result, areas that used to be able to absorb large amounts of water will decrease their ability to absorb rainwater due to changes in function (Wahyuni et al., 2017). The other adverse impact is the decline in the amount of water recharge into the soil causing the groundwater table to drop (Pratama et al., 2014). In this case, the existence of water catchment areas can reduce the amount of water that enters the river. In the end, the people in the middle and downstream of the river could survive the flood. The number of water catchment areas is too little due to the rate of the settlement so that the catchment area becomes a human residence. The dump is also increasing the number of wells that must be made in the area, causing a drought problem (Purwantara, 2013). The function of rainwater catchment areas is not only to control floods but also to save water when the dry season arrives. Dalimunthe et al., (2019) said that the water recharge area is one of the most important parts of the hydrologic cycle that is aimed at passing groundwater, thus determining the stability and sustainability of groundwater. Another action in dealing with disasters is by making bio pore holes.

Table 3

The presence of biopore holes

\begin{tabular}{ccccc}
\hline No & \multicolumn{2}{c}{ Biopore Hole } & \multicolumn{2}{c}{ Percentage } \\
\hline 1. & Have & Don't have & Have & Don't have \\
\hline 2. & 20 & 80 & 20 persen & 80 persen \\
\hline Total & \multicolumn{3}{c}{100} & \multicolumn{2}{c}{100 persen } \\
\hline
\end{tabular}

The existence of biopore holes in the table above provides information that the biopore holes as a way to deal with flooding are not very popular. It is even worse if this method is not applied to disaster-prone areas such as those who live around the Ciliwung River. About 84 percent or about 8 of the total respondents have biopore holes. On one hand, only about 16 percent of respondents have biopore holes, or about 8 respondents. The results of this study are evidence that individual awareness to self-regulate cannot be realized. One way to control flooding is by making biopore holes. Biopore holes do not need large areas of land but are very good for absorbing rainwater. In addition, biopore holes can preserve the soil environment. The biopore infiltration hole that has been formed can be filled with organic waste (in the form of dry leaves, grass clippings, fallen tree branches, and other household organic waste) around the house yard (Elsie et al., 2017).

The use of compost or organic materials is very good for protecting the environment and its functions. Wijaya et al., (2019) when the dry season occurs, water reserves remain available and the plants around them become fertile because they get the organic material from organic fertilizers that are immersed in the biopore hole. At the time of making the biopore hole, a little organic matter is included, such as compost and leaf litter, so the biopore hole also plays a role in loosening the soil. Loose soil encourages the soil to absorb water. At the same time maintaining soil fertility because when organic material is already present in the soil it will directly invited soil decomposers such as earthworms. By ensuring that the biopore holes are not covered by rubbish or rock, it will launch rainwater runoff into it. Thus, the process of replenishing groundwater will run smoothly and reduce flooding in the dry season (Permanasari et al., 2018).

Samadikun, (2019) explains that the presence of biopore infiltration holes will directly increase the water infiltration area, at least as large as the width of the column/wall of the hole. For example, if a hole is made with a diameter of $10 \mathrm{~cm}$ and a depth of $100 \mathrm{~cm}$, the area of infiltration will increase by $3140 \mathrm{~cm} 2$ or nearly $3140 \mathrm{~cm} 2$ or $1 / 3 \mathrm{~m} 2$. In other words, a circular soil surface with a diameter of $10 \mathrm{~cm}$, which originally had an infiltration area of $78.5 \mathrm{~cm} 2$ after a biopore infiltration hole was made with a depth of $100 \mathrm{~cm}$, the area of the infiltration area became $3218 \mathrm{~cm} 2$. In addition to the act of making biopore holes and also the existence of water catchment areas, the presence of plants in the environment also influences and protects the 
1292 The Existence Condition Of Environment And Disaster Literacy At Elementary School Student Mother In Bogor West Java - Bahagia, Fachruddin Majeri Mangunjaya, Rimun Wibowo, Zulkifli Rangkuti DOI: https://doi.org/10.31004/edukatif.v3i4.508

environment from disaster problems. To see the results of the survey research on the presence of plants in the area of the homes of mothers whose children go to elementary school, it can be seen in Table 4 below.

\section{Table 4}

The number of resondent who have tree, fruit tress, and Flower

\begin{tabular}{|c|c|c|c|c|c|c|c|}
\hline No & The numbe & f resondent & oo have & fruit tr & d Flor & & \\
\hline 1 & Fruit Tress & & Tress & & Flow & & other \\
\hline 2 & Have & Don't have & Have & $\begin{array}{l}\text { Don't } \\
\text { have }\end{array}$ & have & $\begin{array}{l}\text { Don't } \\
\text { have }\end{array}$ & \\
\hline Jumlah & 12 & 88 & 30 & 70 & 50 & 50 & 0 \\
\hline Total & 100 & & 100 & & 100 & & 0 \\
\hline
\end{tabular}

The table above illustrates that mothers of elementary school students have not made planting plants behavior. This data shows that there are about 12 people who have fruit trees in their home area, but more than 88 percent of students do not have fruit trees or 88 people. This is the case with tree planting behavior. Only about 30 percent of students own trees at home or about 30 people out of 100 people. Meanwhile, those who do not have trees in the area of the house reach 70 percent or about 70 people. Even so, the student's mother still cultivates ornamental plants such as flowers in the home area. The number of mothers who have flowers reaches 50 people and 50 people who do not have flowers in their home area. If planting has not become a habit, natural disasters will be difficult to control, likewise with environmental problems such as water shortages in the dry season.

When the rainy season arrives, the rainwater cannot be controlled. Plants of any kind have a function to absorb water either a little or a lot. A flower has a function to absorb water. There are differences in the ability to absorb water in plants with deep and shallow roots. In plants that have deep roots, they can make or create soil aggregates so that there are soil pores in the soil so that water can enter the deep soil. The low planting behavior is because many houses do not have yards. Part of the house yard is cemented so that there are no more green spaces. If the land becomes an obstacle, the planting behavior can still be carried out by using hanging pots, using polybag, and small pots and even a roof area is still available to be used as a roof garden. From a religious perspective, preserving the environment is part of noble morals that must be applied to human life. This is to support life as long as it is in the world and keep people from damage and disasters caused by human hands (Masruri, 2014).

Trees also have various benefits including orological benefits, where the roots of the tree are an integral part of the soil so that they can prevent soil erosion. Meanwhile, hydrologically, trees are useful for absorbing rainwater so that an area overgrown by trees has an impact on where the area is never short of water. Meanwhile, climatologically, trees can lower the temperature so that the air becomes cool, fresh, and comfortable (Budiman \& Sunan, 2017). In addition, soil and water conservation measures through planting trees by involving the community is a strategic effort to reduce the danger of erosion and drain rainwater into the soil through the infiltration process (Harisman et al., 2019). This fact is also supported by the fact that planting trees and protecting trees can cope with flood disasters and create an air that is rich in clean and healthy oxygen (Singgih \& Adi, 2018). The lack of the presence of plants as above will be exacerbated by the condition of the behavior that is not able to properly process waste. Garbage is the main problem as a cause of flooding in river areas. Table 5 below illustrates the behavior of the community, especially the mother of students. It can be seen as follows. 
1293 The Existence Condition Of Environment And Disaster Literacy At Elementary School Student Mother In Bogor West Java - Bahagia, Fachruddin Majeri Mangunjaya, Rimun Wibowo, Zulkifli Rangkuti DOI: https://doi.org/10.31004/edukatif.v3i4.508

Table 5

The behavior in garbage management

\begin{tabular}{cccccc}
\hline No & \multicolumn{5}{c}{ Garbage processing } \\
\hline 1. & $\begin{array}{c}\text { Processing and } \\
\text { disposal to } \\
\text { rubbish bin }\end{array}$ & $\begin{array}{c}\text { Processing and } \\
\text { burning }\end{array}$ & Processing & $\begin{array}{c}\text { Throwing in } \\
\text { trash bin }\end{array}$ & Burning \\
\hline 2. & 10 & 10 & 5 & 60 & 15 \\
\hline Total & & & 100 & &
\end{tabular}

Lack of handling of waste in disaster-prone areas is the main cause of flood disasters and climate change problems. Based on the table above, provides information that there is still the mother of students who are not environmentally friendly when processing waste. About 15 percent or 15 respondents still use the method of burning to eliminate waste. Burning trash seems to solve the problem. Trash is immediately lost from the environment and then becomes ashes. Meanwhile, people who dispose of their trash in landfills reached 60 respondents or around 60 percent of the total respondents. Garbage when burned will release carbon emission gas $(\mathrm{CO} 2)$ and methane gas $(\mathrm{CH} 4)$. These emission gases are the main cause of climate change. Wibisono \& Dewi,(2014) stated that burning plastic produces one of the most dangerous materials in the world, namely Dioxins.

Dioxin is one of the few chemicals that has been researched intensively and has been confirmed to cause cancer. Murdiyanto \& Gutomo (2018) stated that organic waste could be involved in river areas, clogging river waterways and causing flooding. Meanwhile, waste disposal then ends at a landfill, which is not a solution. The environment looks clean but it pollutes the new environment. The community around the landfill is affected by the avalanche of rubbish, the unpleasant smell of the garbage, and pollutes the water due to garbage slime and a source of disease for residents. The same is the case with people who still burn garbage because the community is not facilitated to process waste optimally. In addition, people do not understand the impact of burning waste on the climate. Here, environmental education is lacking. Finally, behavior such as harvesting rainwater is a way to deal with flood disasters in rivers. The results of research on the behavior of managing rainwater can be seen in Table 6 below.

Table 6

The behavior in rain water management

\begin{tabular}{ccc}
\hline No & \multicolumn{2}{c}{ The behavior in rain water management } \\
\hline 1. & Deposite & Don't deposite \\
\hline 2. & 30 & 60 \\
\hline Total & 100 & \\
\hline
\end{tabular}

The table above provides information that most respondents do not collect rainwater. About 60 percent or about 60 respondents from the total respondents let the rainwater not be collected. Meanwhile, respondents who collect rainwater are around 30 percent or about 30 respondents. This field data is really surprising because rainwater is not considered a wealth that must be preserved and then stored as water stock for the dry season. As well as a water reserve for household needs (washing, cooking and drinking water purposes) and for other purposes such as watering plants. Unaware behavior to utilize rainwater is the main factor causing flooding in urban and rural areas. Rainwater is not the cause of flooding if the rainwater is managed properly. In principle, people who collect rainwater mean saving rainwater and reducing the risk of flooding. As well as save on economic expenses to buy water. Then, harvesting rainwater also has various benefits. 
1294 The Existence Condition Of Environment And Disaster Literacy At Elementary School Student Mother In Bogor West Java - Bahagia, Fachruddin Majeri Mangunjaya, Rimun Wibowo, Zulkifli Rangkuti

DOI: https://doi.org/10.31004/edukatif.v3i4.508

Rofil, (2017) this rainwater harvesting effort is one of the conservation efforts to maintain adequate water supply in urban areas. Saving rainwater is a form of disaster mitigation because this effort is very meaningful if it is carried out by residents in disaster-prone areas. Flooding due to river overflows can be avoided and at the same time flooding in the village and housing environment cannot occur. In principle, flood management can be completed if it is successful in saving rainwater. Ideally, each household cultivates behavior to save rainwater and store rainwater so that the environment is flood-free.

\section{CONCLUSION AND SUGESTION}

From the result above, there is numerous point of view that can be concluded including the extension in disaster and environment hurdle have been held in mother of student community at Elementary school. Unfortunately, mothers of the student do not often for involving in an extension activity. It refers to the lack of knowledge in environment function and disaster because they have not literate. However, the role of extension training is to scale up the rate of literate in disaster of nature and environment through improving the attitude, knowledge, and behavior of mothers of the students. As they shortage information about disaster clue, they can fail to confront environmental problem and disaster when they hit human life.

The other is the agency of disaster both government and private as well as LSM have a role to the literate disaster of nature. In this, the mothers of the students have renowned the role and the function of disaster agency where they are responsible to refine the rate of the knowledge in societies. The benefit is to jump the level of their literate in disaster. Another is the behavior can be mentioned as the ending of literature. As mothers of the students are aware, high knowledge and attitude, it impacts their behavior because the environment and disaster literation are connected to real action or behavior. For this, the behavior in real action for facing environmental and disaster obstacles has not been conducted properly and fairly.

For example, they have not cultivated trees and other plants like fruit as well as flowers to reduce the risk of disaster. It is similar to behavior where the mothers of the students have not released action to manage their garbage. Sewage is still disposed to the river, burn, and thrown into the trash bin. Also, rainwater as a big problem to trigger flooding has not been harvested despite the rain is valuable for life. If it reacts in action, it can tackle disaster issues in human life. Then, water absorption regions have not as a habit in action to reduce the number of runoff on the surface of the land. It refers to flooding disasters because the rainwater is unable to save underground areas.

\section{THANKS GIVING}

The author team would like to thank LPM Equator Bogor as the agent who has funded this research. At the same time, the authors also express their gratitude to Universitas Ibn Khaldun Bogor for supporting the implementation of this simple research.

\section{REFERENCES}

Afrian, R., \& Islami, Z. R. (2019). Peningkatan potensi mitigasi bencana dengan penguatan kemampuan literasi kebencanaan pada masyarakat Kota Langsa. Jurnal Pendidikan Geografi, 24(1), 132-144. https://doi.org/10.17977/um017v24i22019p132

Andianti, R. Mardiyah, S. \& Purba, W.S. (2020). Statistik Lingkungan Hidup Indonesia. Jakarta: Badan Pusat Statistik.

Brown, L. M., Haun, J. N., \& Peterson, L. (2014). A proposed disaster literacy model. Disaster Medicine and Public Health Preparedness. https://doi.org/10.1017/dmp.2014.43

Budiman, A., \& Sunan, I. K. . (2017). Gerakan Penghijauan Das Citarum Hulu Di Desa Cikoneng Kecamatan Cileunyi Kabupaten Bandung. Jurnal Aplikasi Ipteks Untuk Masyarakat, 6(2), 78-82. 
1295 The Existence Condition Of Environment And Disaster Literacy At Elementary School Student Mother In Bogor West Java - Bahagia, Fachruddin Majeri Mangunjaya, Rimun Wibowo, Zulkifli Rangkuti DOI: https://doi.org/10.31004/edukatif.v3i4.508

Dalimunthe, M. R. B., Suyarto, R., \& Diara, I. W. (2019). Analisis Bentuklahan untuk Menentukan Zona Resapan Air di Lereng Selatan Kawasan Bedugul. Jurnal Agroekoteknologi Tropika, 8(2), 171-181.

Dewi, N. K., \& Rudiarto, I. (2014). Pengaruh Konversi Lahan terhadap Kondisi Lingkungan di Wilayah Periurban Kota Semarang (Studi Kasus: Area Berkembang Kecamatan Gunungpati). Jurnal Pembangunan Wilayah \& Kota, 10(2), 115-126. https://doi.org/10.14710/pwk.v10i2.7641

Elsie, E., Harahap, I., Herlina, N., Badrun, Y., \& Gesriantuti, N. (2017). Pembuatan Lubang Resapan Biopori Sebagai Alternatif Penanggulangan Banjir Di Kelurahan Maharatu Kecamatan Marpoyan Damai Pekanbaru. Jurnal Pengabdian UntukMu NegeRI, 1(2), 93-97. https://doi.org/10.37859/jpumri.v1i2.242

Gheith, E. (2019). Environmental literacy among prospective classroom teachers in Jordan. International Journal of Learning, Teaching and Educational Research, 18(12), 258-279. https://doi.org/10.26803/ijlter.18.12.15

Harisman, K., Frasetya, B., Sudrajat, A., Birnadi, S., \& Sholeha, M. (2019). Penanaman Pohon Sebagai Upaya Menjaga Cadangan Air Tanah Dan Mencegah Bahaya Erosi Di Kecamatan Cibiru. Al-Khidmat, 2(1), 34-39. https://doi.org/10.15575/jak.v2i1.5344

Harisuseno, D., Rispiningtati, Andawayanti, U., Suhartanto, E., WWS, A., \& Oktavianto, S. D. H. (2013). Studi Sebaran Kawasan Resapan (Permeable Area) Pada Berbagai Tipe Penggunaan Lahan. Jurnal Teknik Pengairan, 4(1), 1-5.

Hidayat, A. (2017). Penjelasan Teknik Purposive Sampling Lengkap Detail - Uji Statistik. In Statistikian.

Indri Safitri, W., Suryawati, E., \& Yustina, Y. (2020). Environmental Literacy Analysis of Junior High School Students in Pekanbaru. Journal of Educational Sciences, 4(1116-123).I https://doi.org/10.31258/jes.4.1.p.116-123

Indriantoro, I. (2014). Pengetahuan Masyarakat Terhadap Mitigasi Bencana Kekeringan di Kecamatan Tawangsari Kabupaten Sukoharjo. Universitas Muhammadiyah Surakarta.

Khairuddin, Yamin, M., Syukur, A., \& Kusmiyati. (2019). Penyuluhan Tentang Upaya Pelestarian lingkungan Hidup pada Siswa SMPN 3 Palibelo Kabupaten Bima. Jurnal Pendidikan Dan Pengabdian Masyarakat, 2(2), 239-248.

Kurniawati, D., \& Suwito, S. (2019). Pengaruh Pengetahuan Kebencanaan Terhadap Sikap Kesiapsiagaan Dalam Menghadapi Bencana Pada Mahasiswa Program Studi Pendidikan Geografi Universitas Kanjuruhan Malang. JPIG (Jurnal Pendidikan Dan Ilmu Geografi), 2(2), 135-142. https://doi.org/10.21067/jpig.v2i2.3507

Kusumastuti, R. D., \& Kurniawan, A. (2020). Membangun Siswa Tangguh Bencana di Cimanggu Pandeglang. Journal of Sustainable Community Development (JSCD), 2(18-16). https://doi.org/10.32924/jscd.v2i1.6

Leksono, S. M., Nestiadi, A., Andriana, E., Firdausy, A., Nurjanah, E., Shofa, M., \& Marianingsih, P. (2020). Identifikasi komponen literasi lingkungan di buku biologi SMA. Prosiding Seminar Nasional Pendidikan FKIP Universitas Sultan Ageng Tirtayasa.

Marlyono, S. G. (2017). Pengaruh Literasi Informasi Bencana Terhadap Kesiapsiagaan Masyarakat dalam Menghadapi Bencana di Provinsi Jawa Barat. Jurnal Geografi Gea, 16(2). https://doi.org/10.17509/gea.v16i2.4491

Masruri, U. N. (2014). Pelestarian Lingkungan dalam Perspektif Sunnah. At-Taqaddum, 6(2411-428).

Meilinda, H., Prayitno, B. A., \& Karyanto, P. (2017). Student's Environmental Literacy Profile Of Adiwiyata Green School In Surakarta, Indonesia. Journal of Education and Learning (EduLearn), 11(3), 299-306. https://doi.org/10.11591/edulearn.v11i3.6433

Murdiyanto, M., \& Gutomo, T. (2018). Flood and Landslide Natural Disasters and Its People Prevention Effort. Jurnal Penelitian Kesejahteraan Sosial, 14(4), 437-452.

Nugraha, B. A., Widana, I. D. K. K., Wilopo, Hidayat, R., \& Sakti, S. K. (2020). Peran Pangkalan Tni Al 
1296 The Existence Condition Of Environment And Disaster Literacy At Elementary School Student Mother In Bogor West Java - Bahagia, Fachruddin Majeri Mangunjaya, Rimun Wibowo, Zulkifli Rangkuti DOI: https://doi.org/10.31004/edukatif.v3i4.508

Balikpapan Dalam Penanggulangan Bencana Alam Di Wilayah Kerjanya. Nusantara: Jurnal Ilmu Pengetahuan Sosial, 7(2), 352-360.

Permanasari, E., Hendola, F., Purisari, R., \& Safitri, R. (2018). Penyelamatan Air Tanah dan Penanggulangan Sampah Melalui Program Biopori Dan Komposter Di Pemukiman Kecil di Kelurahan Ciputat dan Ciputat Timur. Jurnal Pengabdian Kepada Masyarakat, 4(1), 51-64. https://doi.org/10.22146/jpkm.33412

Prastiwi, L., Sigit, D. V., \& Ristanto, R. H. (2020). Hubungan Antara Literasi Ekologi Dengan Kemampuan Memecahkan Masalah Lingkungan Di Sekolah Adiwiyata Kota Tangerang. Jurnal Pendidikan Matematika Dan IPA, 11(147-61). https://doi.org/10.26418/jpmipa.v11i1.31593

Pratama, N., Gunawan, A., \& Besperi. (2014). Pemanenan Air Hujan untuk Konservasi Tanah Melalui Sumur Resapan. Inersia, 6(2), 31-44.

Priyono. (2016). Metode Penelitian Kuantitatif (T. CHANDRA (ed.)). Zifatama Publishing.

Priyowidodo, G., \& Luik, J. E. (2013). Literasi Mitigasi Bencana Tsunami untuk Masyarakat Pesisir di Kabupaten Pacitan. Ekotrans, 13(147-61).

Purwantara, S. (2013). Resapan Buatan, Solusi Mengatasi Problema Air. Informasi, 1(XXXIX), 43-58. https://doi.org/10.21831/informasi.v0i2.4443

Purwantara, S. (2015). Dampak Pengembangan Permukiman Terhadap Air Tanah di Wilayah Yogyakarta dan Sekitarnya. Geoedukasi, IV(1), 31-40.

Puspasari, H. (2017). Peran Palang Merah Indonesia Terhadap Penanggulangan Dampak Bencana Alam di Indonesia. Buletin Penelitian Sistem Kesehatan, 20(4), 149-155.

Puspitasari, D. (2014). Tingkat Pengetahuan Siswa Kelas VII Dalam Mitigasi Bencana Gempa Bumi Di Smp Negeri 1 Prambanan Kabupaten Klaten. Universitas Muhammadiyah Surakarta.

Resubun, E. E. R., Tarore, R. C., \& Takumansang, E. D. (2015). Analisis Pemanfaatan Ruang Pada Kawasan Resapan Air Di Kelurahan Ranomuut Kecamatan Paal Dua Kota Manado. Spasial, 2(2), 174-182.

Rofil. (2017). Potensi dan Multifungsi Rainwater Harvesting (Pemanenan Air Hujan) di Sekolah bagi Infrastruktur Perkotaan. Biology Education Conference, 14(1), 247-251.

Rusmawan. (2017). Ecoliteracy Dalam Konteks Pendidikan Ips. SOSIO DIDAKTIKA: Social Science Education Journal, 4(2), 39-50.

Samadikun, B. P. (2019). Penerapan Biopori untuk Meningkatkan Peresapan Air Hujan di Kawasam Perumahan. Jurnal Presipitasi: Media Komunikasi Dan Pengembangan Teknik Lingkungan, 16(3), 126-132.

Sasikome, J., Kumaat, L., \& Mulyadi, N. (2015). Pengaruh Penyuluhan Bencana Banjir Terhadap Kesiapsiagaan Siswa Smp Katolik Soegiyo Pranoto Manado Menghadapi Banjir. Jurnal Keperawatan UNSRAT, 3(2), 1-8.

Singgih, M., \& Adi, P. (2018). Pengenalan tanaman hijau bumiku. Jurnal Abdikarya: Jurnal Karya Pengabdian Dosen Dan Mahasiswa, 1(1), 69-71.

Supriandi, S. (2020). Faktor-Faktor Yang Berhubungan Dengan Kesiapsiagaan Keluarga Dalam Menghadapi Bencana Di Kota Palangka Raya. Avicenna : Journal of Health Research, 3(128-41). https://doi.org/10.36419/avicenna.v3i1.340

Syamaun, S. (2019). Pengaruh Budaya Terhadap Sikap Dan Perilaku Keberagamaan. At-Taujih: Bimbingan Dan Konseling Islam, 2(2), 81-95. https://doi.org/10.22373/taujih.v2i2.6490

Utaya, S., \& Bachri, S. (2019). Ecological Literacy Siswa SMA Adiwiyata dan Non Adiwiyata. Jurnal Pendidikan: Teori, Pendidikan, Dan Pengembangan, 4(4), 499-503.

Veisi, H., Lacy, M., Mafakheri, S., \& Razaghi, F. (2019). Assessing environmental literacy of university 
1297 The Existence Condition Of Environment And Disaster Literacy At Elementary School Student Mother In Bogor West Java - Bahagia, Fachruddin Majeri Mangunjaya, Rimun Wibowo, Zulkifli Rangkuti DOI: https://doi.org/10.31004/edukatif.v3i4.508

students: A case study of Shahid Beheshti University in Iran. Applied Environmental Education and Communication, 18(1), 25-42. https://doi.org/10.1080/1533015X.2018.1431163

Wahyuni, W., Arsyad, U., Bachtiar, B., \& Irfan, M. (2017). Identifikasi Daerah Resapan Air di Sub Daerah Aliran Sungai Malino Hulu Daerah Aliran Sungai Jeneberang Kabupaten Gowa. Jurnal Hutan Dan Masyarakat, 9(2), 93-104. https://doi.org/10.24259/jhm.v9i2.2891

Wibisono, A. F., \& Dewi, P. (2014). Sosialisasi Bahaya Membuang Sampah Sembarangan dan Menentukan Lokasi TPA di Dusun Deles Desa Jagonayan Kecamatan Ngablak. Jurnal Inovasi Dan Kewirausahaan, $3(1), 21-27$.

Widyaningrum, N., Kodar, M. S., Purwanto, R. S., \& Priambodo, A. (2020). Peran TNI dalam Penanggulangan Bencana Alam (Studi Kasus Peran Korem 043/Gatam dalam Penanggulangan Bencana Alam di Provinsi Lampung). Journal of Education, Humaniora and Social Sciences (JEHSS), 5(1), 4048. https://doi.org/10.34007/jehss.v3i1.150

Wijaya, S. A., Soebiyakto, G., \& Ma'sumah, M. (2019). Pembuatan Lubang Resapan Biopori Dan Pupuk Kompos Cair Dari Sampah Di Rw Ix, Kelurahan Kalirejo, Kecamatan Lawang, Kabupaten Malang. Jurnal Aplikasi Dan Inovasi Ipteks "Soliditas" (J-SOLID), 2(2), 59-66. https://doi.org/10.31328/js.v2i2.1343

Wilujeng, I., Dwandaru, W. S. B., \& Rauf, R. A. B. A. (2019). The effectiveness of education for environmental sustainable development to enhance environmental literacy in science education: A case study of hydropower. Jurnal Pendidikan IPA Indonesia, 8(4), 521-528. https://doi.org/10.15294/jpii.v8i4.19948

Yaslina, Y., \& Taufik, R. A. (2018). Pengaruh Pemberian Edukasi Terhadap Perilaku Kesiapan Masyarakat Dalam Menghadapi Bencana Banjir Di Kecamatan Bonjol Kabupaten Pasaman. Prosiding Seminar Kesehatan Perintis, 1(1), 1-7.

Yumantoko. (2019). Kolaborasi Para Pihak Dalam Penanganan Destinasi Wisata Terdampak Bencana Di Taman Nasional Gunung Rinjani Stakeholder Collaboration in Handling Disaster-Based Tourism Destination in The Rinjani Mountain National Park. Journal of Forestry Research, 3(1), 15-28.

Yusuf, Z. K., \& Kurnia Mangile, F. (2019). Pengaruh Penyeluhan Terhadap Tingkat Pengetahuan Masyarakat Menghadapi Bencana Banjir. Jambura Nursing Journal, 1(2), 48-55. https://doi.org/10.37311/jnj.v1i2.2425

Yanuarto, T., Pinuji, s., Utomo, A.C., \& Satrio, I.T. (2019). Buku Saku Tanggap Tangkas Tangguh Menghadapi Bencana. Jakarta: BNPB. 